\title{
The Stone Slurry in Palestine from Environmental Burden to Economic Opportunities-Feasibility Analysis
}

\author{
Nabil Al-Joulani' ${ }^{1}$, Nidal Salah ${ }^{2}$ \\ ${ }^{1}$ College of Engineering and Technology, Palestine Polytechnic University, Hebron, Palestine \\ ${ }^{2}$ Bethlehem University, Bethlehem, Palestine \\ Email: njoulani@ppu.edu, nsalah82@yahoo.com
}

Received 22 June 2014; revised 18 July 2014; accepted 12 August 2014

Copyright (C) 2014 by authors and Scientific Research Publishing Inc.

This work is licensed under the Creative Commons Attribution International License (CC BY). http://creativecommons.org/licenses/by/4.0/

(c) (i) Open Access

\begin{abstract}
This research will examine the potentially economic, environmental, and political impacts for recycling the stone slurry in Palestine through utilization of this slurry in the ready mix concrete industry. The utilization concept is concluded in incorporation of the stone slurry as a partial replacement of the fine ingredient of the concrete mix which is the natural sand, based on several empirical studies that have proved the possibility for this utilization. The proposed utilization would result in a rather integration between these two main economic sectors: stone industry, and ready mix concrete industry. The results of this research revealed significant economic and environmental gains in terms of money and natural resources saved if partial replacement of natural sand with fresh stone slurry has been adopted.
\end{abstract}

Keywords

Palestine, Stone Slurry, Utilization, Ready Mix Concrete

\section{Introduction}

As the stone industry in Palestine constitutes one of the most important pillars of the national economy in one hand, and as this industry generates huge amount of the stone waste particularly stone slurry in other hand, then establishing strategies to support this sector as well as to mitigate the environmental severe consequences for its waste are inevitable requirements for the sustainable development in the border national context.

Palestine's stone is almost the sole utilized natural resource that exports abroad and helps mitigating the unbalance in the National Trade Balance; it contributes to 30\% of the national exports [1], and thus, stone industry

How to cite this paper: Al-Joulani, N. and Salah, N. (2014) The Stone Slurry in Palestine from Environmental Burden to Economic Opportunities-Feasibility Analysis. Journal of Environmental Protection, 5, 1075-1090.

http://dx.doi.org/10.4236/jep.2014.512106 
in Palestine constitutes a main pillar of the national economy. A major stone cutting facility is shown in Figure 1.

Globally, Palestine occupied the $12^{\text {th }}$ rank of the stone producers worldwide in 2002 [3]. As Palestine's stone production is equivalent to half Germany's production and around one third Turkey's stone production. It generates more than 20,000 jobs for the Palestinian labor market [4].

According to many empirical studies conducted on the stone slurry waste in and outside Palestine, there is a robust conclusion that has proved the possibility of utilization of the stone slurry in the concrete mixes, which will not only mitigate the environmental impact of the stone industry, but also contribute to generating economic gains.

In Palestine the environmental impact of stone slurry waste resulted from quarries and stone processing industry is devastating; affecting air quality, surface and ground water, and contaminated agricultural soil. The major component of stone slurry is the calcium carbonate. This compound is accumulated in the ditches and on the soil surface, causing the formation of lime cemented hard pans that restrict infiltration of water and root penetration into the soil layer [6]. Types and distributions of stone facilities in Palestine are shown in Figure 2.

Many stone cutting facilities used to collect the stone slurry in holes around the plants exist in the populated areas (Figure 3 and Figure 4), thus they cause hazardous objects that may kill people, animals, and plants. On the other hand, the slurry generated from this industry in many cases is disposed in the municipal sewer system causing blockage in these networks and many harms consequences [7], and when it is transported to landfills and open areas, it pollutes the surrounding and causes poor soil fertility and penetrates to the ground water. Moreover, when slurry becomes dry, the resulted powder flies and deposits on agricultural lands and vegetations harshly affect the environment and the ecosystem. On the other hand, the accumulation of waste in landfills is also a pressing problem for many economic activities from economic point of view [8].

Recycling stone sludge is extremely new field of research in Palestine. Despite the evident empirical progress achieved in the stone slurry recycling industry worldwide, the emergence of this new promising industry has not been occurred yet in Palestine.

In many developed and developing countries, particularly those in which the stone industry sector occupy a significant rank in their economy, the utilization of the stone slurry has witnessed considerable applications on

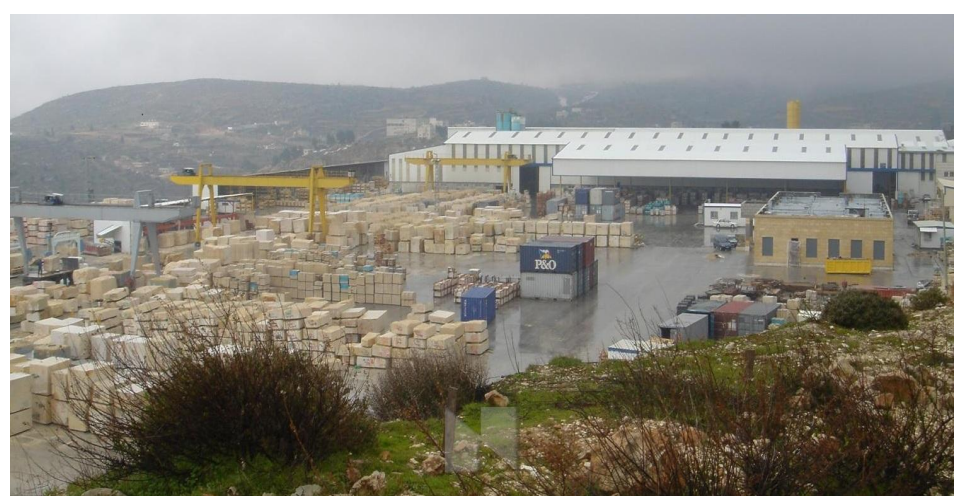

Figure 1. Stone facility in Bethlehem—Nassar Stone [2].

Stone Cutting
Facilities
Stone Workshops
Quarries
Crushers

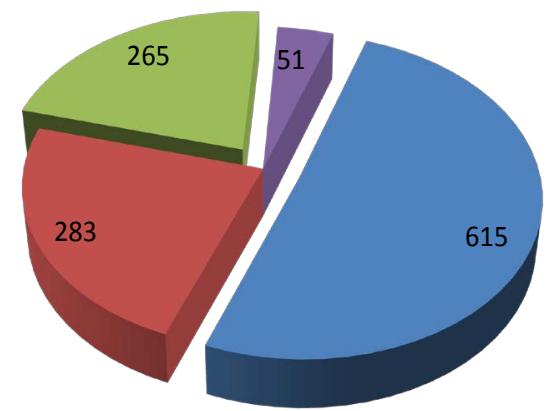

Figure 2. Stone facilities types distributions in 2013 [5]. 


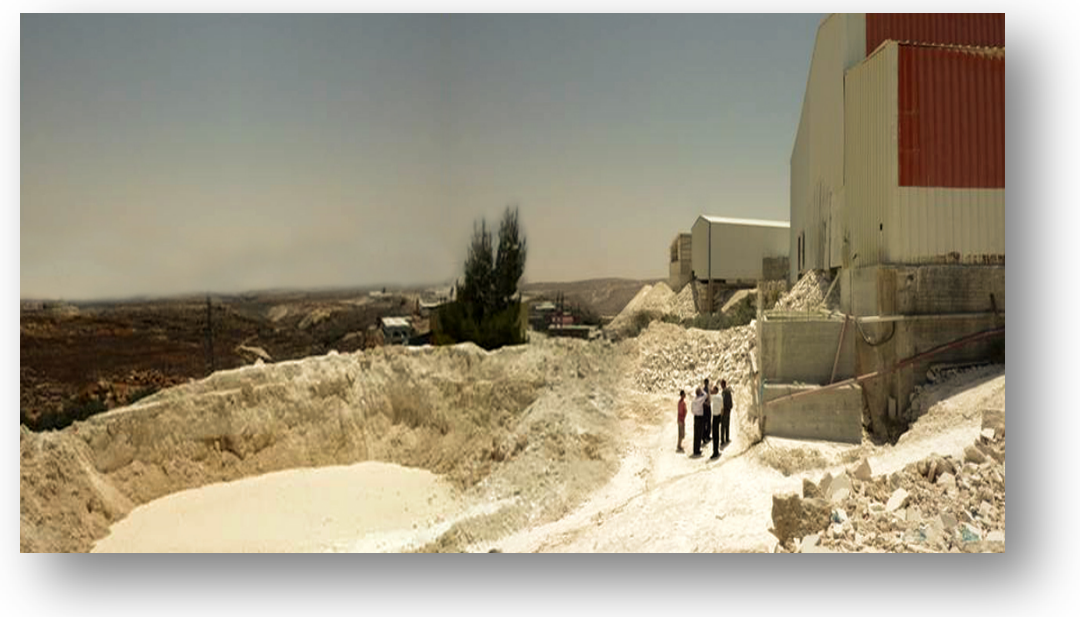

Figure 3. Stone slurry collected in an open hole near stone facility [7].

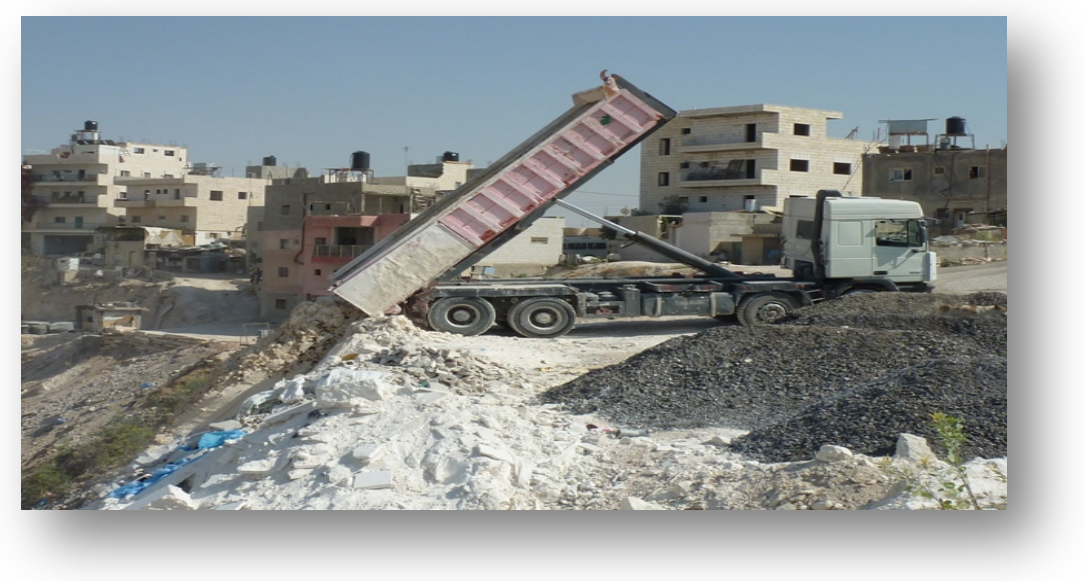

Figure 4. Stone slurry waste discharge near populated areas [7].

the ground. However, in Palestine, the situation is extremely different from those countries despite the fact that the Palestinian stone industry is considered one of the most important economic sector as well as it forms the largest manufacturing activities [5], the utilization of stone slurry has not been tackled practically yet.

This paper examines the potentially economic and environmental gains that shall be associated with the utilization of the stone slurry in ready mix concrete industry in Palestine, also it provides feasibility analysis of the impact of this utilization on the stone cutting industry and the ready mix concrete industry in Palestine. The utilization will be through partial replacement of the fine ingredient of the concrete produced by the ready mix concrete factories with the stone slurry in Palestine.

\section{Literature Review}

Many studies conducted throughout the world to examine the potential applications of the stone slurry waste, the studies performed based on laboratory testing for this material. The results of these studies highlighted that the stone slurry waste may be used in many industries and could be incorporated in many construction materials which may realize two main objective; the first one is getting rid of this environmental burden that causes many environmental harms. The second objective is to seek economic opportunities through the profit gained by this utilization.

The stone slurry has wide industrial applications, basically in construction sector, for instance in cement in- 
dustry, tiles, pavement, embankment, marble, producing glues and paints. Other industries also as paper industry could have the opportunities to benefit from these materials. Moreover, agriculture acidic soils can be moderated by mixing with granite powder to moderate it's acidity as well as this powder can be used in fertilizer [8].

There are many studies investigated the potential recycling of stone slurry waste in PCV pipes, tiles and cellular cement and Y-tong blocks [4] [9].

The use of stone slurry in the production of building blocks is safe for health and environment [10], as well as it enhancing the compressive strength of concrete block [11]. Other study suggest that the stone slurry can be used with $25 \%$ of the water content in concrete mix after a settling process of 30 minutes which will save water and reduce the environmental pollution and reduce the production cost as well [12].

Many recent studies have been proved that the stone and marble slurry could be incorporated in the concrete mixes. For instance; a study motivated by reducing the environmental burden of this waste and reducing the cost of concrete as an efficient way to sustainable development of the construction sector in India has proved that adding $15 \%$ of marble dust not only it will help to get rid of this heavy environmental burden, but also it will enhance the concrete compressive strength in all concrete mixes. The experiment conducted by replacing different percentages by weight of fine aggregate with stone slurry in the concrete Grade M30 mix [13].

More comprehensive study conducted to examine the possibility to replace one hundred percent of fine aggregate in the concrete mix with stone dust as well as to examine the change in the compressive strength and the durability properties in the proposed stone dust concrete according to different codes and standard, the results of this research demonstrates the similarity between quarry rock dust and natural sand in terms of chemical and physical characterizations. This study gives also a comprehensive investigation not only to the compressive strength of concrete but also to almost all other engineering properties of the concrete, like acid attack resistance, water absorption, drying shrinkage strain, and permeability. Thus the mentioned study concluded that there is a possibility to replace one hundred percent of the fine aggregate (sand) with quarry rock dust in the concrete mix that will resulted in an increase in the compressive strength of around $10 \%-12 \%$, as well as the durability of quarry rock dust concrete under sulphate and acid attack is higher than that of the conventional concrete. Moreover, this modified concrete demonstrated less permeability compared to the conventional concrete. However, at the same time the researcher call for more researches and trail casting in order to reach and adopt the optimum water content and mix proportion to fit the required workability and strength [14].

In Palestine, there is also an examination for the utilization of the stone slurry powder in the concrete mixes as a partial replacement by weight of the natural sand has conducted and demonstrated that the replacement of $20 \%$ of natural sand in the concrete mixes with the stone slurry powder is a completely safe process, given that this stone slurry is of Palestinian origin.

The conclusion of the above empirical studies is so obvious that the possibility and applicability of the utilization of the stone slurry in the concrete mixes has a robust experimental base.

\section{Quantities and Quality of the Palestinian Stone Slurry}

The topic of recycling the stone slurry in Palestine has occupied a significant promising field in Palestine recently. According to the most updated and comprehensive study in stone waste management field that examined the quantity of the slurry generated in Palestine, there is 750,000 cubic meters of liquid slurry generated annually in the West Bank and 185,000 cubic meters generated annually of dry slurry that called cake as shown in Figure 5, this type is produced by pressing the liquid slurry. Thus the potential cake that may produced if all stone cutting factories used pressing machines is around half million cubic meters per year. On the other hand, to examine the quality of this material as the chemical and physical characteristics of this material is crucial in determining the potential industries this material may be utilized in, 9 samples of the stone slurry were tested in Ramallah in two independent laboratories and 3 samples were sent to Italy and tested for the first time to identify this material's characterization. The results of this tests highlighted that Calcium Carbonate which is the main constitute of this material characterize with high purity between $94 \%$ - 98\% purity of Calcium Carbonate, as well as tests showed the absence of pollutants and low percentages of chemical elements, such as Fe, alkali metals. Consequently, these tests confirmed high potential use of the Palestinian slurry in commercial applications [7]. The characteristics of Palestinian stone slurry are shown in Table 1.

\section{Ready Mixed Concrete in Palestine}

In fact ready mix concrete in not a new construction technology in Palestine, its use refer to many decades ago 


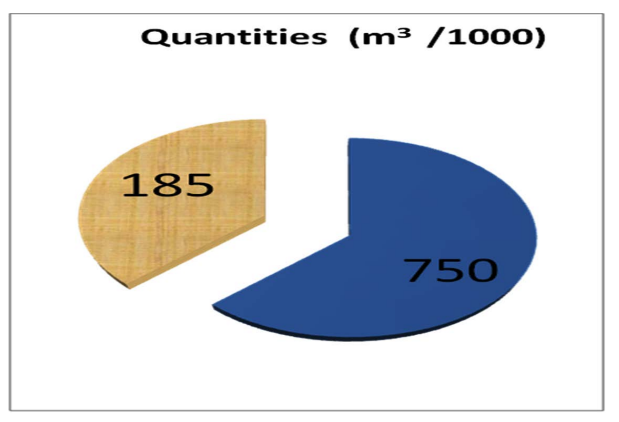

Figure 5. Stone slurry quantity in Palestine [7].

Table 1. Chemical and physical characterizations of Palestinian stone slurry [7].

\begin{tabular}{|c|c|c|}
\hline Mineralogical & Chemical & Physical \\
\hline $\mathrm{CaCO}_{3}$ & $\mathrm{Cu}$ & Grain size distribution \\
\hline $\mathrm{CaCO}_{3}+\mathrm{MgCO}_{3}$ & $\mathrm{Mg}$ & Oil sorption \\
\hline $\mathrm{Fe}_{2} \mathrm{O}$ & $\mathrm{Mn}$ & \\
\hline $\mathrm{Al}_{2} \mathrm{O}_{3}$ & As & \\
\hline $\mathrm{Fe}_{2} \mathrm{O}+\mathrm{AlO}_{3}$ & $\mathrm{~Pb}$ & \\
\hline $\mathrm{SiO}_{2}$ & $\mathrm{Fe}$ & \\
\hline \multirow[t]{8}{*}{$\mathrm{CaO}$} & $\mathrm{P}$ & \\
\hline & Alkali metals & \\
\hline & $\mathrm{Hg}$ & \\
\hline & FI & \\
\hline & LoI & \\
\hline & $\mathrm{pH}$ & \\
\hline & Acids insoluble & \\
\hline & $C>12$ & \\
\hline
\end{tabular}

as this technology provide extra three main advantages than the cast in place concrete; the first advantage is the possibility to place the concrete in high or difficult places. Second, when there is no enough space available to mix large quantities of concrete and the third advantage is that ready mixed concrete is become more feasible and it is easier to control its quality, thus the use of the ready mixed concrete is growing within the time in Palestine and throughout the world as well [15].

According to a survey conducted in year 2002 the number of ready mix concrete companies was 36 companies in the West Bank [15]. In 2014, the number of these companies is almost doubled due to the increase in the population and the corresponding increase in the construction sector. According to the PCSC's sales manager who works for the company which is almost sole provider of cement to the Palestinian market the number of the ready mix concrete companies today is 67 companies [16]. Therefore, it is obvious that there is a significant increase in the demand on the ready mix concrete in the Palestinian markets as the number of the ready mix concrete factories jumped during the last 12 years. Accordingly more concern must be directed toward this crucial industrial sector in Palestine.

\section{Optimum Product}

Utilization of the Palestinian stone slurry in the ready mix concrete is the optimum current possible solution for the environmental and economic challenges associated with the stone industry, this conclusion in fact is due to 
many considerations that characterize the ongoing Palestinian reality. However, this argument does not mean that this option is the sole valid option for exploitation of the stone slurry waste, but it is the most simple and achievable option that match the Palestinian economic and environmental context at this time. Moreover, the other utilization options may be resulted in much more gains like the production of high quality of calcium carbonate, paper industries, paints, and tiles but these options need much more technologies, higher investment cost, and more complicated logistics.

Therefore, the researcher chooses this option (Ready Mix Concrete) as the center of this study for the following considerations;

First, the growing demand on the concrete as a basic construction material in the previous two decades to meet the steady population growth and the new political reality that strongly influence the aggregate economy and put high risk of the investment in other economic sectors.

Second, the practicality of the concrete that has been proved in the construction sector and the absence of other competitive alternative material in Palestine.

Third, the steady increase demand in the ready mix concrete whereas the majority of the new buildings activities are tend toward adopting the vertical building, thus the ready mix concrete is undoubtedly more efficient choice than the cast-in place concrete.

Fourth, in order to increase the integration between the stone cutting industry and concrete mix industry.

Based on the survey conducted in this study, the number of running ready mix concrete companies in Bethlehem Governorate is 10 companies, given that Bethlehem district is relatively witness a moderate pace of construction activities when it compared with other Governorate like Ramallah, Hebron, or Nablus.

Fifth, the traditional investment mentality dominated in Palestine, unfortunately is tend not to take up the challenge and risks of establishing new manufacturing activities that need high technology and cost much money, thus utilization of the stone slurry in the ready mix concrete as it do not need a high technology nor it costs a lot of money to initiate the business make it the optimum option rather than utilizing it in the production of other market's products that may need high investment cost and require high technology.

Sixth, the utilization of stone slurry instead of sand in the concrete mix would conserve a non renewable natural resource which is the sand and mitigate the depletion of this material thus creating new sustainable development engine in addition to getting rid of a heavy devastating environmental burden which is the stone slurry.

Finally, the bulk of the concrete consumed in Palestine is ready mix concrete thus it makes sense to stimulate the innovation to get rid of the majority of the stone slurry amount produced each year through following this path.

For all the above reasons, the core of this research is concentrated on how to utilize the stone slurry in the production of ready concrete mixes with certain proportions and to what extent this utilization resulted in environmental and economic gains

\section{Possible Scenarios}

The utilization of stone slurry in the ready mix concrete can be achieved by two possible scenarios, in both scenarios the existence of an intermediate station in which this proposed raw material is subjected to preparation process prior to be incorporating in the concrete mix, is a necessity.

The first scenario, which is highlighted by many researchers in the previous literature of this issue that is by converting the stone slurry starting with this material in its semi solid state as it disposed from the slurry pressers existed in the stone cutting facilities, then two stages shall be accomplished, we have to dry the slurry to convert it to a dry material, then grinding it and converting it to a powder material that is ready to be used in the concrete mix.

The other possible scenario, is to use the stone slurry without subjecting it to drying nor grinding, but by liquidate it, all what shall be given when this material delivered to the ready mix concrete factories is the water content of this material in order to deduct the quantity of water which is contained in the stone slurry from the water quantity that supposed to be used in the concrete mix, which is the suggested scenario for utilization recommended in this study as elaborated in the following sections.

\subsection{The Powder Slurry Scenario}

In this scenario the stone slurry will be transported from stone facilities and collected in an intermediate plant in 
order to be treated before the utilization process. The utilization process shall include two main stages; the first stage is the drying stage, in which the water content of the slurry is reduced to almost zero. This stage needs large drying machines (Oven) to be used in order to produce commercial quantities of slurry. The second stage, is the grinding stage, in which the resulted dried cake from the first stage is converted to slurry powder using grinding machines, thus the resulted material is a powder material that shall be transported to the ready mix concrete factories to be used in the concrete mixes as a dry material replaced the sand partially in the concrete mixes as shown in the simple illustration of production line in the Figure 6.

\subsection{The Semi Solid Slurry Scenario}

In this scenario the stone slurry is transported to the intermediate plant, where it shall be standardized with a certain water content. This process is accomplished easily by measuring the water content in the delivered slurry and adding the certain suitable proportion of water to this slurry in order for this material to be more close to the liquid state before it transported to the ready mix concrete factories to be used in the concrete mixes as a semi solid material contains certain quantity of water content that shall be deducted from the water quantity supposed to be needed for the traditional concrete mixes. All equipments that needed for this scenario in the intermediate plant is a stone slurry mixers that shall provide the ready mix concrete factories with a material that is close to liquid state-homogenous material for the transporting tanks that deliver the slurry to the ready mix concrete companies to be incorporated in the mixes as a partial replacement of sand and water. Simple illustration of production line is shown in Figure 7.

\subsection{Optimum Scenario}

Based on the field investigations conducted by the researcher and the comparison performed between the above two scenarios, the second scenario is recommended due to the following considerations:

1) Higher technology and more expensive equipments required in the first scenario than that required in the second one.

2) Large amount of energy needed to convert the (semi-solid) stone slurry from its state to be completely dry material then large energy needed to grind this dry material to convert it to a powder materia. However, this energy might be saved in the second scenario.

3) Contrary to the first scenario, the amount of water in the (semi-solid) stone slurry will not be wasted in the

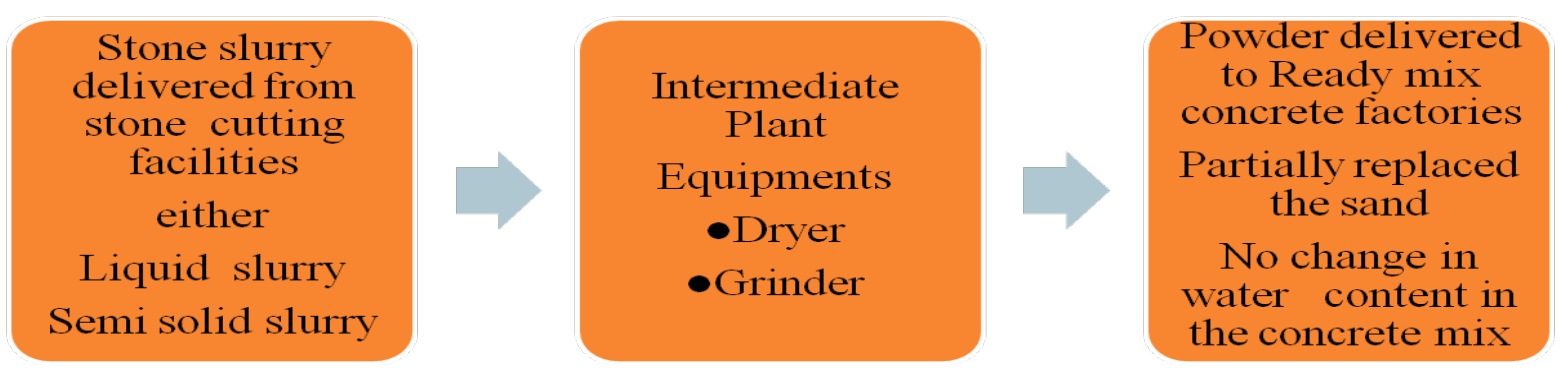

Figure 6. Production line for the powder scenario.
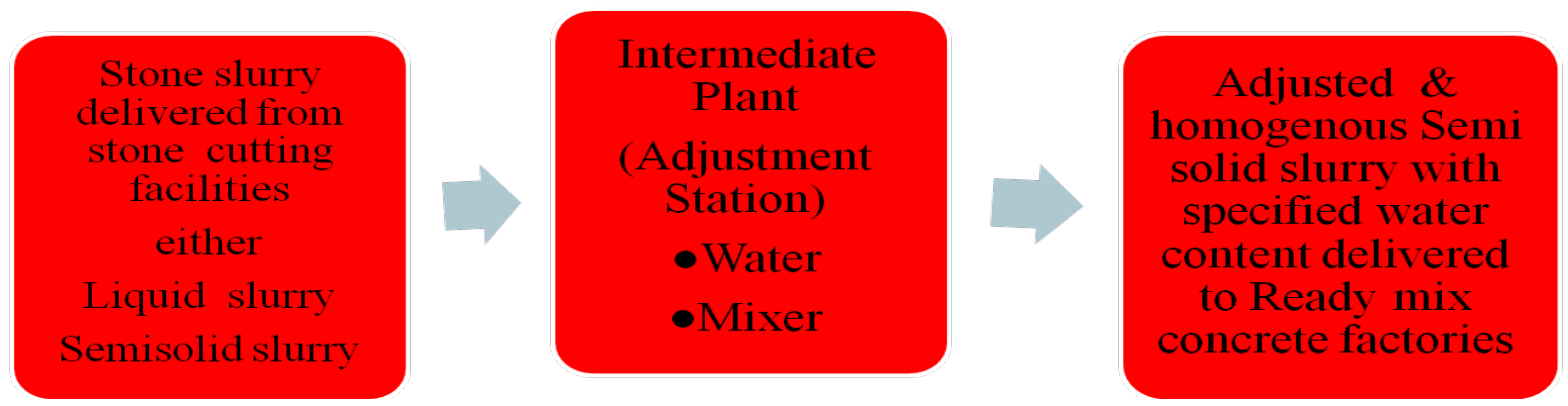

Figure 7. Production line for the semi solid slurry scenario. 
second scenario, thus this scenario save also another natural resource which is hardly to obtain and relatively expensive in Palestine.

4) The transportation method required in the second scenario is more likely will be more practical than that of the first scenario, since the late require special tanked that is completely isolated in order not to allow any moisture content to be entered to the powder.

5) The area of the intermediate plant is more likely to be larger in the first scenario than that needed for the second scenario.

\section{Methodology}

The methodology adapted in this research was principally based on mixed approach between qualitative and quantitative analysis, particularly, the following researching tools were used:

1) Site test for a sample of fresh Palestinian stone slurry that tested in an independent laboratory.

2) Site visits for several stone cutting facilities in Palestine to realize the manufacturing techniques used and the environmental impact of the stone slurry waste as well as to pick some illustrating photos to be shown in this report.

3) Conducting interviews with many ready mix concrete factories in different districts in Palestine to examine the interaction of these people with the utilization concept as they form the most probable entrepreneurs.

4) Conducting interview with the southern area director of the Palestinian Standards Institution.

5) Attending and participating in the most recent events that tackle the topic of research in Palestine.

\section{Research Results}

\subsection{Site Test}

This test was conducted for two main reasons; the first one, is to examine the possibilities of incorporating Palestinian fresh stone slurry in its status just as it disposed from the filter presses machines, given that all the reviewed relevant studies either use the stone slurry as a powder material or as liquid material in the concrete mixes. The other reason is to provide more assurance in the rationality and applicability of the utilization concept locally.

The sample was taken from a filter press machine in stone cutting factories in Bethlehem and sent to Al-Tarifi Ready Mix Concrete Co who in turn sent it to the GMT laboratory in Ramallah.

The concrete mixes were prepared for of (B300) conventional concrete and for stone slurry concrete in which $15 \%$ of natural sand was replaced with stone slurry. The percentage $15 \%$ was suggested by the author in order to examine the properties of the concrete with this intermediate ratio.

The concrete mixes' samples were prepared on the 27th March 2014 in GMT laboratory in Ramallah, the samples were prepared as conventional concrete mixes and as the proposed mixes with $15 \%$ natural sand replacement with stone slurry.

The water content in the stone slurry sample was examined and it was determined before preparing the mixes in order to deduct the water amount in the stone slurry from the required water for the concrete mix. It was found that the water content in the stone slurry is $28 \%$.

Compressive strength tests were conducted on these different samples on conventional testing dates (3 days, 7 days, 14 days, and 28 days) the tests results of the tested samples are shown in Table 2.

The results shown in the above table are so indicative and relevant, as the required compressive strength of the concrete with stone slurry is supposed to be $300 \mathrm{Kg} / \mathrm{cm}^{2}$ on the 28 days curing. The result shown in the above table gave us robust evidence on the possibility of the utilization of the stone slurry in the concrete mixes in its status as it disposed from the filter press machines. Even though this test is very limited and simple, it provided the empirical tool to assure the utilization concept rationality, since the used stone slurry was utilized as it without any further treatment.

\subsection{Ready Mix Concrete-Cluster Analysis}

The Ready Mix Concrete Companies Questionnaire served in two key issues; in one hand, it provided the researcher with the necessary data for the potential gains that might be associated with the utilization of stone slurry in the ready mix concrete industry, and on the other hand, it indirectly examined to what extent the ready 
Table 2. Effect of stone slurry on compressive strength of concrete (B300).

\begin{tabular}{|c|c|c|c|c|}
\hline Sample & $\begin{array}{l}\text { Compressive } \\
\text { strength at } 3 \text { days }\end{array}$ & $\begin{array}{c}\text { Compressive } \\
\text { strength at } 7 \text { days }\end{array}$ & $\begin{array}{l}\text { Compressive } \\
\text { strength at } 14 \text { days }\end{array}$ & $\begin{array}{l}\text { Compressive } \\
\text { strength at } 28 \text { days }\end{array}$ \\
\hline Conventional concrete & 188.6 & 309.3 & 332 & 367 \\
\hline $\begin{array}{c}\text { Concrete with } 15 \% \text { replacement of stone slurry } \\
\text { instead of natural sand }\end{array}$ & 169.6 & 265.1 & 315.6 & 328 \\
\hline
\end{tabular}

mix concrete factories' owners were stimulated by the utilization concept as the questionnaire gave them the chance to calculate the potential monthly save in terms of money per cubic meter of concrete produced by their plants.

The questionnaire is consisted of 16 questions and it was distributed and collected in the period between 22nd of February to 20th of March. It was filled by 16 ready mix concrete companies different in size and production as they selected randomly. The selected companies are distributed in six districts; Bethlehem, Al-Quds (AlAzaria), Hebron, Ramallah, Tulkarem, and Nablus.

This questionnaire contains some questions that related to the potential economic gains that may be associated with the utilization process. These questions may be left unfilled and the answer can be calculated by the researcher. Given that the questionnaire contained specific data that must be filled by a specialist person in the company, then the questions related to the potential save for the particular plant are clear to the person who answered them that they could be calculated from the given information in the questionnaire and that the researcher can find out them automatically by his own calculations. Thus this gave us an indication about the degree of the motivation associated with the utilization concept in the side of concrete companies' owners.

The indication was rather positive since that more than $56 \%$ of the sample population were stimulated by the utilization concept and positively interact with the questionnaire as he/she has completed the answers, which is a positive indication about the rationality of this new method in the eyes of the Palestinian entrepreneurs.

The questionnaire is basically designed to estimate the total quantity of concrete produced natural sand consumed by the ready mix concrete factories in West Bank. This was done by calculating the quantity of natural sand consumed by the questionnaire's sample companies as well as the quantity of concrete produced then from these quantities the average ratio of sand/concrete (which is the amount of natural sand in ton used per each cubic meter of ready mix concrete) was obtained. The average production of concrete for the ready mix concrete factories was calculated from the questionnaire sample, then this amount is multiplied by the number of total running ready mix concrete companies in the West Bank which is 67 companies to find out the total amount of cubic meters of ready mix concrete produced in the West Bank, through which the total amount of natural sand consumed by the ready the mix concrete companies was find out. This figure provided us with the total potential save if we utilize the stone slurry as a substitution of natural sand with certain proportions in the ready mix concrete industry. Moreover, to check the creditability of the data collected by the questionnaire the first question in this questionnaire is about the amount of cement consumed by each of the sample's company in order to calculate the aggregate amount of cement consumed by the ready mix concrete companies in West Bank and compare the resulted value with the estimated quantity of ready mix concrete resulted from the aggregate cement consumption that was disclosed by the key speakers of the Palestinian Commercial Services Company (PCSC) which is the sole provider of cement to the Palestinian market. If the two obtained values are close together then we can trust the results obtained by the questionnaire. Table 3 shows the calculated annual amounts of concrete produced, cement consumed, and natural sand consumed by the ready mix concrete companies of the sample, as a forward step to estimate the aggregate amounts of these ingredients of all ready mix concrete companies in the West Bank. Table 4 shows the questionnaire basic data in annual basis.

Table 5 summarizes the data obtained through the questionnaire.

\subsection{Estimation of the Total Consumption of Cement}

Number of ready mix concrete companies in West Bank = 67 companies [16].

Number of ready mix concrete companies of the sample $=16$ companies.

The average production of each ready mix concrete company per month $=5130 \mathrm{~m}^{3}$.

The average production of each ready mix concrete company per year $=61,558 \mathrm{~m}^{3}$. 
Table 3. Questionnaire basic data.

\begin{tabular}{|c|c|c|c|c|c|}
\hline $\begin{array}{l}\text { Sample } \\
\text { number }\end{array}$ & District & $\begin{array}{l}\text { Monthly production of } \\
\text { concrete }\left(\mathbf{m}^{3}\right)\end{array}$ & $\begin{array}{l}\text { Monthly consumption of } \\
\text { cement (ton) }\end{array}$ & $\begin{array}{l}\text { Monthly consumption of } \\
\text { sand (ton) }\end{array}$ & $\begin{array}{l}\text { Sand price } \\
\text { (NIS) }\end{array}$ \\
\hline 1 & Bethlehem & 3800 & 1100 & 2600 & 80 \\
\hline 2 & Bethlehem & 8333 & 2167 & 5667 & 80 \\
\hline 3 & Bethlehem & 1700 & 600 & 1200 & 84 \\
\hline 4 & Bethlehem & 300 & 120 & 120 & 80 \\
\hline 5 & Bethlehem & 8330 & 2250 & 5664 & 70 \\
\hline 6 & Bethlehem & 4000 & 900 & 3000 & 80 \\
\hline 7 & Bethlehem & 3300 & 1000 & 2145 & 80 \\
\hline 8 & Ramallah & 16,000 & 3500 & 2000 & 70 \\
\hline 9 & Hebron & 3000 & 1000 & 2100 & 45 \\
\hline 10 & Hebron & 6000 & 2100 & 4200 & 66 \\
\hline 11 & Hebron & 4000 & 1260 & 2800 & 60 \\
\hline 12 & Hebron & 6667 & 1667 & 4167 & 80 \\
\hline 13 & Tulkarem & 2850 & 1000 & 2280 & 75 \\
\hline 14 & Jerusalem & 1000 & 350 & 720 & 80 \\
\hline 15 & Jerusalem & 2500 & 700 & 775 & 90 \\
\hline 16 & Nablus & 10,297 & 3302 & 6500 & 76 \\
\hline
\end{tabular}

Table 4. Questionnaire basic data in annual basis.

\begin{tabular}{|c|c|c|c|c|}
\hline $\begin{array}{l}\text { Sample } \\
\text { number }\end{array}$ & District & $\begin{array}{l}\text { Annual production of } \\
\text { concrete }\left(\mathrm{m}^{3}\right)\end{array}$ & $\begin{array}{l}\text { Annual consumption of } \\
\text { cement (ton) }\end{array}$ & $\begin{array}{l}\text { Annual consumption of sand } \\
\text { (ton) }\end{array}$ \\
\hline 1 & Bethlehem & 45,600 & 13,200 & 31,200 \\
\hline 2 & Bethlehem & 100,000 & 26,000 & 68,000 \\
\hline 3 & Bethlehem & 20,400 & 7200 & 14,400 \\
\hline 4 & Bethlehem & 3600 & 1440 & 1440 \\
\hline 5 & Bethlehem & 99,960 & 27,000 & 67,968 \\
\hline 6 & Bethlehem & 48,000 & 10,800 & 36,000 \\
\hline 7 & Bethlehem & 39,600 & 12,000 & 25,740 \\
\hline 8 & Ramallah & 192,000 & 42,000 & 24,000 \\
\hline 9 & Hebron & 36,000 & 12,000 & 25,200 \\
\hline 10 & Hebron & 72,000 & 25,200 & 50,400 \\
\hline 11 & Hebron & 48,000 & 15,120 & 33,600 \\
\hline 12 & Hebron & 80,000 & 20,000 & 50,000 \\
\hline 13 & Tulkarem & 34,200 & 12,000 & 27,360 \\
\hline 14 & Jerusalem & 12,000 & 4200 & 8640 \\
\hline 15 & Jerusalem & 30,000 & 8400 & 9300 \\
\hline 16 & Nablus & 123,564 & 39,624 & 78,000 \\
\hline \multicolumn{2}{|c|}{$\sum$} & 984,924 & 276,184 & 551,184 \\
\hline
\end{tabular}


Table 5. Summary of the questionnaire’s data for 16 companies.

\begin{tabular}{|c|c|c|}
\hline Item & Unit & Amount \\
\hline Total concrete production of the (16) sample companies & $\mathrm{m}^{3} /$ year & 984,924 \\
\hline Total cement consumption of the (16) sample companies & ton/year & 276,184 \\
\hline Total sand consumption of the (16) sample companies & ton/year & 551,184 \\
\hline Average ration of (cement/concrete) of the (16) sample companies & $\operatorname{ton} / \mathrm{m}^{3}$ & 0.3043 \\
\hline Average ratio of (sand/concrete) of the (16) sample companies & $\operatorname{ton} / \mathrm{m}^{3}$ & 0.6163 \\
\hline Average price of sand of the (16) sample companies & NIS/ton & 74.75 \\
\hline Average concrete production of the (16) companies sample per month & $\mathrm{m}^{3}$ & 5130 \\
\hline
\end{tabular}

The average production of all West Bank's ready mix concrete companies per year $=4,124,369 \mathrm{~m}^{3}$.

The average cement proportion in the cubic meter of ready mix concrete $=0.3043 \mathrm{ton} / \mathrm{m}^{3}$.

The average consumption of cement for all West Bank's ready mix concrete companies $=0.3043 \times 4,124,369$ $=1,255,045$ ton/year.

This estimated value obtained from the questionnaire's calculations, is equivalent to that obtained from other source of data which is the sole provider of cement to the Palestinian market.

According to the PCSC the aggregate consumption of cement of the Palestinian market is around 1.5 million ton/year [16].

And according to a construction materials survey conducted in the Palestinian territories, about 3/4 of the concrete produced in the Palestinian territories is ready mixed concrete which is close to the ratio of (Ready Mixed/Cast in Place) concrete in other countries [15].

Thus, according to this data the aggregate cement consumption for the ready mix concrete companies $=0.75$ $\times 1,500,000=1,125,000$ ton/year. Since the two estimated values of total cement consumption are very close, then this promise in more reliable in the research approach, and reassure us that values obtained from the questionnaire are trustfully with less than $10.4 \%$ deviation between the two values obtained differently.

\subsection{Estimation of the Ready Mix Concrete Total Consumption of Natural Sand}

The same way of calculations was followed to find out the total amount of natural sand consumed by the ready mix concrete companies, the average proportion of sand per cubic meter of ready mix concrete is equal to $0.6163 \mathrm{ton} / \mathrm{m}^{3}$.

Then the total amount of sand consumed by all ready mix concrete factories in the West Bank equal the total amount of cubic meters of ready mixed concrete produced each year by all concrete factories multiply by the average tons of sand per cubic meter of concrete $=4,124,369 \times 0.61653=2,541,849$ ton/year.

\subsection{Potential Save}

This section is devoted to highlight the amounts of save in natural sand which will be reflected not only in two or more economic and environmental gains but also in political gain in terms of realizing more independence from the Israelis sources of sand as follows:

-Replacement of only $10 \%$ of natural sand with stone slurry will result of 2,541,849 $\times 0.1=254,185$ ton/year. Given that the average price of natural sand $=74.75$ NIS/ton obtained from the questionnaire data, then the potential in term of money $=254,184 \times 74.75=19,000,329$ NIS, equivalent to US $\$ 5,475,599$.

Figure 8 and Figure 9 summarize the potential saved quantities per different proportions of replacement of stone slurry instead of natural sand:

In addition to these savings "values" a crucial ingredient of the concrete product that become very limited and difficult to obtain nowadays is the fresh water. The estimated amount of fresh water consumed by the ready mix concrete companies alone touch the value of half million cubic meters per year, which make this industry and the stone industry as well being the largest two consumers of fresh water among all other industries. Thus, this foster the integration concept between the ready mix concrete and the stone industries through the substitution of 


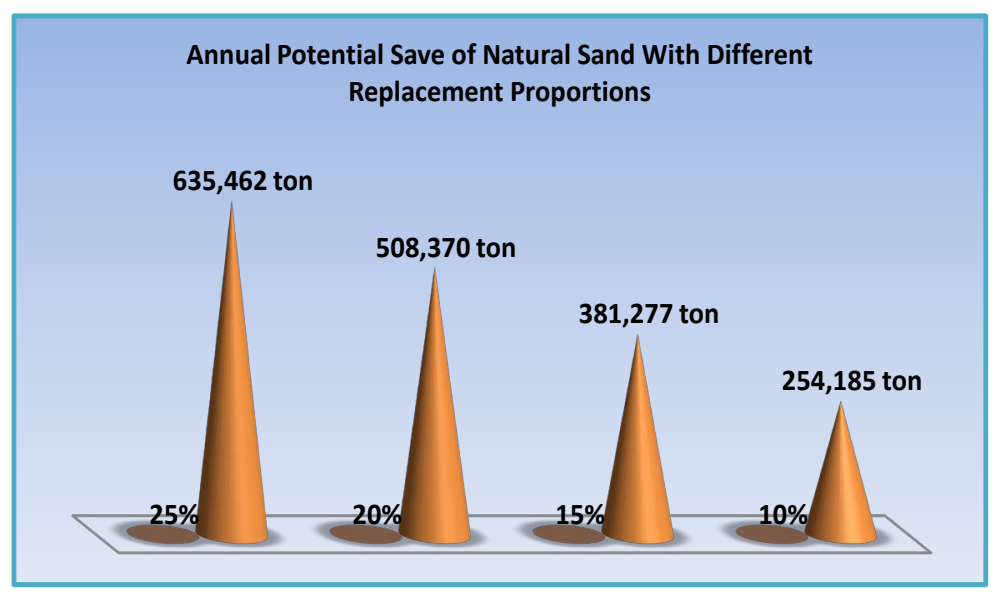

Figure 8. The annual potential save of natural sand.

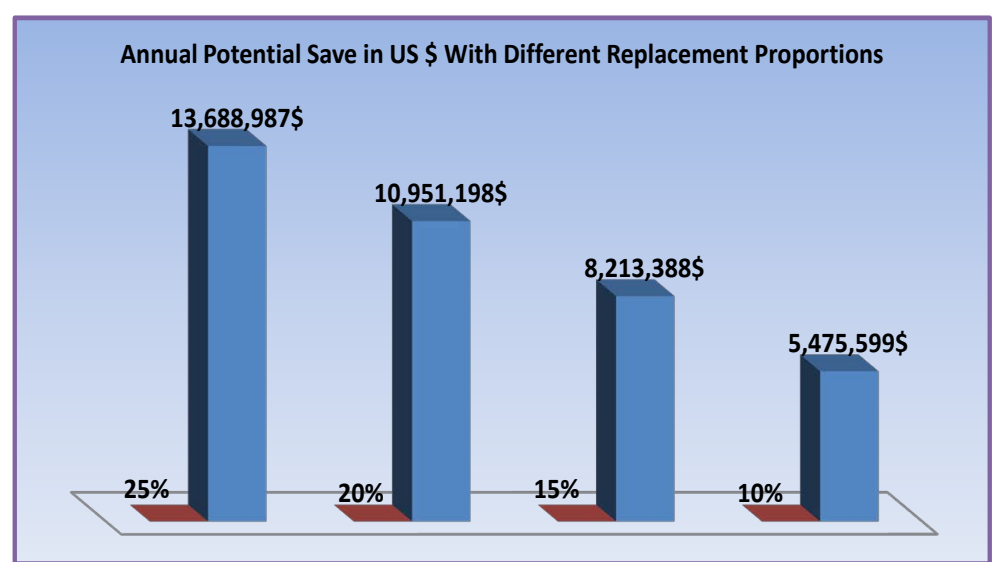

Figure 9. The annual potential save in US dollars.

the stone slurry in ready mix concrete that would have not only has environmental and economic returns, but also would promise of rather a political gain in terms of offering more resources that usually imported or purchased from the Israelis. Furthermore, if we assumed that the water content in the pressed wet cake as the site test detects to be $28 \%$ the associated save in fresh water per year will be as follows:

-In the case of $10 \%$ replacement $=254,185 \times 0.28=\left(71,172 \mathrm{~m}^{3} /\right.$ year $)$.

-In the case of $15 \%$ replacement $=381,277 \times 0.28=\left(106,758 \mathrm{~m}^{3} /\right.$ year $)$.

-In the case of $20 \%$ replacement $=508,370 \times 0.28=\left(142,344 \mathrm{~m}^{3} /\right.$ year $)$.

-In the case of $25 \%$ replacement $=635,462 \times 0.28=\left(177,929 \mathrm{~m}^{3} /\right.$ year $)$.

Figure 10 illustrates the potential water quantity saved for different utilization percentage of stone slurry.

\subsection{Questionnaire Results' Summary}

The following table summarizes the key resulted figures of this questionnaire is shown in Table 6 .

Table 7 shows the potential saving in terms of natural sand and fresh water as well as in terms of money according to the replacement ratio adopted for the utilization of stone slurry in ready mix concrete industry, given that the price of the cubic meter of fresh water is (4) NIS $/ \mathrm{m}^{3}$ equivalent to (1.15) $\mathrm{USD} / \mathrm{m}^{3}$.

The values in the first column represent also the quantities of the stone slurry that we getting rid of without environmental harm.

As mentioned previously the expected cost of 1 ton of stone slurry ready to be used in the concrete mixes is around 20 NIS which is almost the cost of reduced water quantity existed in the stone slurry, thus Table 8 shows the average potential save expected for each concrete companies; 


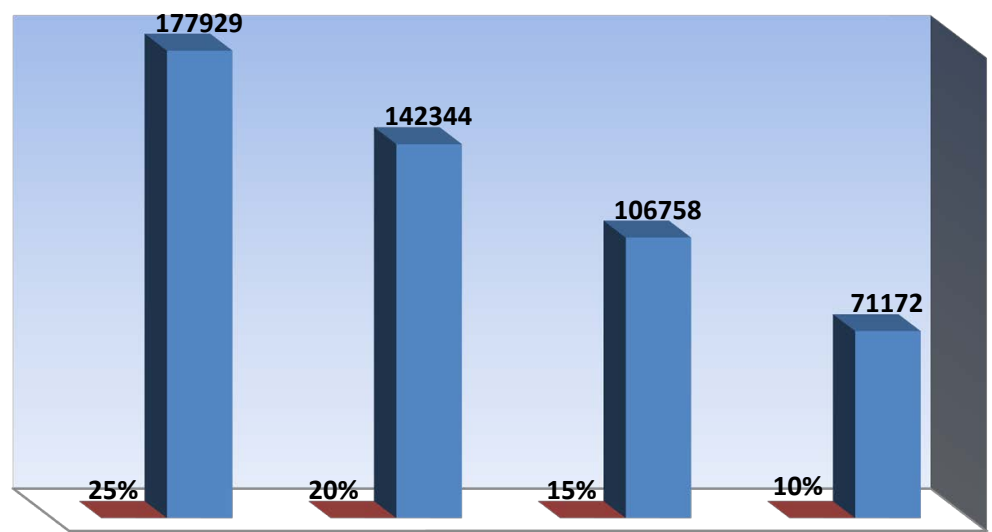

Figure 10. The potential water quantity saved.

Table 6. Summary of the questionnaire' results.

\begin{tabular}{|c|c|c|}
\hline Item & Unit & Value \\
\hline Average total amount of concrete produced by each ready mix concrete factory per year & $\mathrm{m}^{3}$ & 343,710 \\
\hline Total amount of concrete produced by all ready mix concrete factories per year & $\mathrm{m}^{3}$ & $4,124,369$ \\
\hline Average amount of natural sand associated with each cubic meter of produced ready mix concrete & $\operatorname{ton} / \mathrm{m}^{3}$ & 0.6343 \\
\hline Average amount of natural sand consumed by each ready mix concrete factory per year & ton & 37,938 \\
\hline Total amount of natural sand consumed by all ready mix concrete factories per year & ton & $2,541,849$ \\
\hline
\end{tabular}

Table 7. Summary of the utilization's potential save.

\begin{tabular}{|c|c|c|c|c|}
\hline Replacement ratio & $\begin{array}{c}\text { Annual save in } \\
\text { natural sand (ton) }\end{array}$ & $\begin{array}{l}\text { Corresponding } \\
\text { annual save (USD) }\end{array}$ & $\begin{array}{c}\text { Corresponding annual save in } \\
\text { water }\left(\mathrm{m}^{3}\right)\end{array}$ & $\begin{array}{l}\text { Corresponding annual save in } \\
\text { water cost (USD) }\end{array}$ \\
\hline $10 \%$ & 254,185 & $5,475,599$ & 71,172 & 82,042 \\
\hline $15 \%$ & 381,277 & $8,213,388$ & 106,758 & 123,064 \\
\hline $20 \%$ & 508,370 & $10,951,198$ & 142,344 & 164,085 \\
\hline $25 \%$ & 635,462 & $13,688,987$ & 177,929 & 205,106 \\
\hline
\end{tabular}

Table 8. Average potential save expected per concrete company.

\begin{tabular}{ccccc}
\hline $\begin{array}{c}\text { Replacement } \\
\text { ratio }\end{array}$ & $\begin{array}{c}\text { Annual save in natural sand per } \\
\text { concrete company (ton) }\end{array}$ & $\begin{array}{c}\text { Corresponding annual Corresponding annual save } \\
\text { save (USD) }\end{array}$ & $\begin{array}{c}\text { Corresponding annual } \\
\text { in water } \mathbf{( m}^{\mathbf{3}} \text { ) }\end{array}$ & 1063 \\
\hline $\mathbf{s a v e}$ in water cost (USD)
\end{tabular}

\section{Conclusions}

\subsection{Economical Impact}

As the results show the economic impact of the utilization of the stone slurry in the ready mix concrete companies in Palestine is so significant in terms of money and natural resources as well (natural sand, and fresh water).

If we have to adopt a replacement ratio for stone slurry of (15\%) instead of natural sand as this was the ratio used in the concrete mix for the site test conducted in this study, then the annual potential economic gains in 
terms of money will be $(8,336,452)$ USD and in terms of save in natural sand will be $(381,277)$ tons and in terms of fresh water will be $(106,758) \mathrm{m}^{3}$.

Undoubtedly these economic gains will also contribute to the reduction of the production cost of the stone industry and the ready mix concrete industry in Palestine as well, and so raise the feasibility of these two industry which will resulte in more profits and more investments in these two sectors, consequently generate new jobs opportunities.

\subsection{Enviromental Impact}

One of the main shortages in the stone cutting technologies used in Palestine which reflected in heavier environmental impact is that around $90 \%$ of the stone cutting facilities do not use filter press machines which results in a large amount of water losses, increase in the production cost, and more severe environmental damages associated with this semi liquid material compared to that disposed from the filter press machines which has almost solid state with significantly less amount of waste in general. In addition, the use of these machines would make the transportation and recycling of this material is easier as well as these machines save water through recycling the cooling water used in the cutting processes.

The main environmental problems associated with status quo of stone industry in Palestine particularly that resulted from the uncontrolled dumping of the stone slurry:

1) Physical hazards, as stone slurry in that form is constituting real risk on the life of humans and animals, giving that many stone facilities are located near the populated areas collect this material in open holes without taking the suitable safety measures and controls.

2) Soil pollution as the stone slurry is highly alkali material, thus it affect the fertility of the soil particularly since this material is frequently dumped in or near agricultural lands.

3) Water pollution, as this material reduce the soil permeability to the rain water which affect the underground water recharge, and amplify the storm water drainage problem.

4) Air pollution, as this slurry become dry powder the problem of air pollution appear in a dramatic manner, the stone dust cause several harms to the human being, animals, and plants.

According to the above mentioned environmental damages associated with the stone industry waste in Palestine, particularly the stone slurry as it form the crucial part of waste of the stone cutting activities, therefore, adopting new waste management techniques, new utilization proposals, and new recycling methods are urgent needs for the sustainable development of this basic economic sector in Palestine as well as these proposals will be consistent with the main global trend in dealing with such industry as they contribute to achieve the highest attainable level of human rights and population's well beings as required by the international conventions that Palestine is involved in or seeking to involved in.

\subsection{Recommendations}

The waste management approach is the wider umbrella under which the modern methods to mitigate the environmental impact of the industry's best techniques of using the natural resources, and recycling processes of the industrial waste are all fall below. The recycling of the industrial waste is the more sustainable and environmental friendly category among all the waste management categories.

\subsubsection{Enviromental Impact}

Given the status quo of the stone waste industry in Palestine, particularly the fine stone waste that resulted from the stone cutting facilities in the West Bank, it is obvious that used method are neither support the stone sector economic sustainability nor they considering the environmental damages that resulted from this waste. Thus the following recommendations should be highlighted to the Palestinian policy makers in order to adopt more sustainable environmentally regulations, practices, and projects regarding this key economic sector in Palestine:

1) Support, Encourage, and facilitate the possession of the stone facilities of the filter press machines directly or indirectly through NGOs channels that have been working in Palestine.

2) Adopt policies and regulations that criminalize the random dumping of the stone waste particularly the fine waste type (slurry) in Wadis, open areas, and agricultural lands.

3) Promote and facilitate more recycling potentials of the stone slurry in Palestine since there are many studies proved that the characterization of the Palestinian stone slurry allowed for many possible valuable applica- 
tions.

\subsubsection{Utilization of Stone Slurry in Ready Mix Concrete Industry}

In Palestine, as the governmental sector is rather weak and used to play a negative role in stimulation of the innovation in the various economic sectors, then the potential leading sector for the utilization of the stone slurry in concrete mixes or so to say the socio-economic integration between the two industries: the stone industry and the ready mix concrete industry as well, is the private sector, particularly the ready mix concrete factories' owners as they constituted the direct beneficiaries.

The following issues are unsatisfied researching points in this study that need to be satisfied by other studies and investigations in order to implement the proposed integration between the two sectors:

1) Further and more comprehensive laboratory tests on the stone slurry's replacement instead of natural sand in the concrete mixes, to determine the optimum replacement proportions.

2) Investigation of the long-term effect-if exists—of the stone slurry additive is called folk land used in the stone cutting facilities in order to accelerate the sedimentation process of the fine particles to provide more water recycling efficiency.

3) In case of existence of a short- or long-term effect of the folk land additive on the concrete mix, a control system should be installed concerning the percentages added to the stone slurry and the required additives needed to cancel the folk land effect.

4) More empirical studies would determine the optimum water content of the stone slurry to facilitate the incorporation process in the concrete mixes.

5) Further technical studies regarding the intermediate plants would joint the integration process between the stone cutting facilities and the ready mix concrete companies.

6) Further studies would provide completed detailed mechanism concerning the preparation requirements and the required additives of the stone slurry before delivering it to the ready mix concrete factories.

7) The PNA as an official party shall encourage and facilitate the coordination of the efforts between the different parties; basically the ready mix concrete companies’ owners, the stone cutting facilities' owners and the PSI in order to adopt the utilization process on the national level.

\section{References}

[1] The Current Status of Industrial Sector in Palestine (2009) Palestinian Federate. http://www.pfi.ps/site_images/file/Final\%20PFICarana\%20Industrial\%20Sectors\%20Study.pdf

[2] NASSAR STONE WEBSITE. http://www.nassarstone.com/?q=production/quarries

[3] Sultan, S. (2014) Innovation and Stone and Marble Growth. In: Sustainable Stone \& Marble Industry: Clean Production, Waste Management, and Eco-Innovation, Ramallah.

[4] Al-Joulani, N. (2007) Effect of Stone Slurry Waste on Strength, Permeability and Compressibility of Clayey and Sandy Soils. Jordan Journal of Applied Science, 9, 99-111.

[5] Hushaysh, M. (2014) Environmental Initiatives in the National Export Strategy of Stone \& Marble Sector. In: Sustainable Stone \& Marble Industry: Clean Production, Waste Management, and Eco-Innovation, Ramallah.

[6] Al-Joulani, N. (2008) Soil Contamination in Hebron District Due to Stone Cutting Industry. Jordan Journal of Applied Science, 10, 37-50.

[7] (2013) USAID Compete Project Presentation "From Waste to Profit Transforming Stone Slurry Into New Products". USM.

[8] Shirazi, E.K. (2011) Reusing of Stone Waste in Various Industrial Activities. 2nd International Conference on Environmental Science and Development I PCBEE, 4, 217-219.

[9] Al-Joulani, N. (2011) Sustainable Utilization of Stone Slurry Waste in the West Bank. Geo-Frontiers, Dallas, 13-16.

[10] Aukour, F.J. (2009) Incorporation of Marble Sludge in Industrial Building Eco-Blocks or Cement Bricks Formulation. Jordan Journal of Civil Engineering, 3.

[11] Rajgor, M. and Pitroda, J. (2013) Stone Sludge: Economical Solution for Manufacturing of Bricks. International Journal of Innovative Technology and Exploring Engineering (IJITEE), 2, 16-20.

[12] Al-Zboon, K.K. and Mahasneh, K.N. (2009) Effect of Using Stone Cutting Waste on the Compression Strength and Slump Characteristics of Concrete. International Journal of Civil Engineering, 1, 168-173.

[13] Vidyanagar, V., et al. (2013) Marble Waste: Opportunities For Development of Low Cost Concrete. International Re- 
search Analysis, 2, 94-96.

[14] Nada, R.P., Das, A.K. and Moharana, N.C. (2010) Stone Crusher Dust as a Fine Aggregate in Concrete for Paving Blocks. Intternational Journal of Civil and Structural Engineering, 1.

[15] Energy Code For Building (2002) Construction Materials \& Local Market Survey in Palestinian Territories. http://www.molg.pna.ps/ecb/studies/material/material.pdf

[16] Palestine News Network (2014) Palestinian Commercial Services Co: We Offer One Million and Half Ton of Cement Annually for Palestinian Market. 20. 
Scientific Research Publishing (SCIRP) is one of the largest Open Access journal publishers. It is currently publishing more than 200 open access, online, peer-reviewed journals covering a wide range of academic disciplines. SCIRP serves the worldwide academic communities and contributes to the progress and application of science with its publication.

Other selected journals from SCIRP are listed as below. Submit your manuscript to us via either submit@scirp.org or Online Submission Portal.
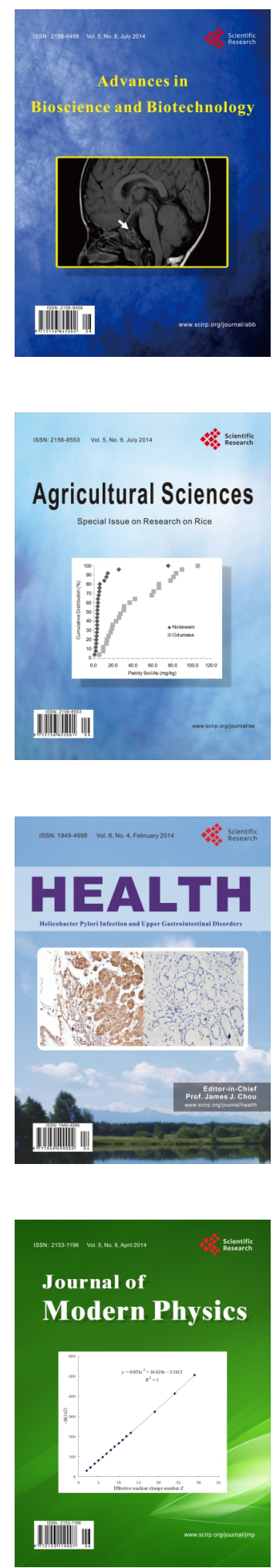
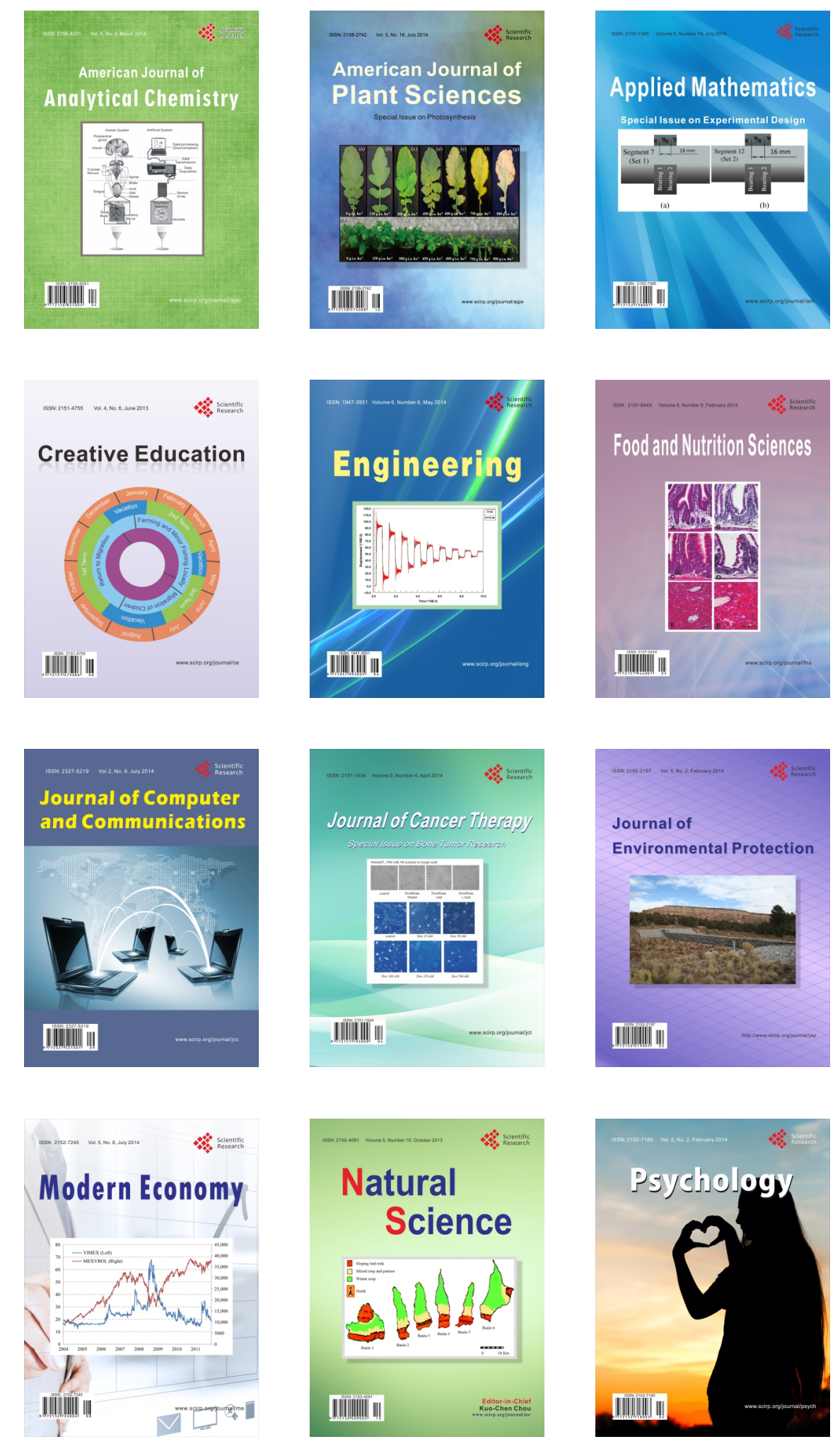